\title{
Carbon dioxide, climate and the deep ocean circulation: Carbon chemistry model
}

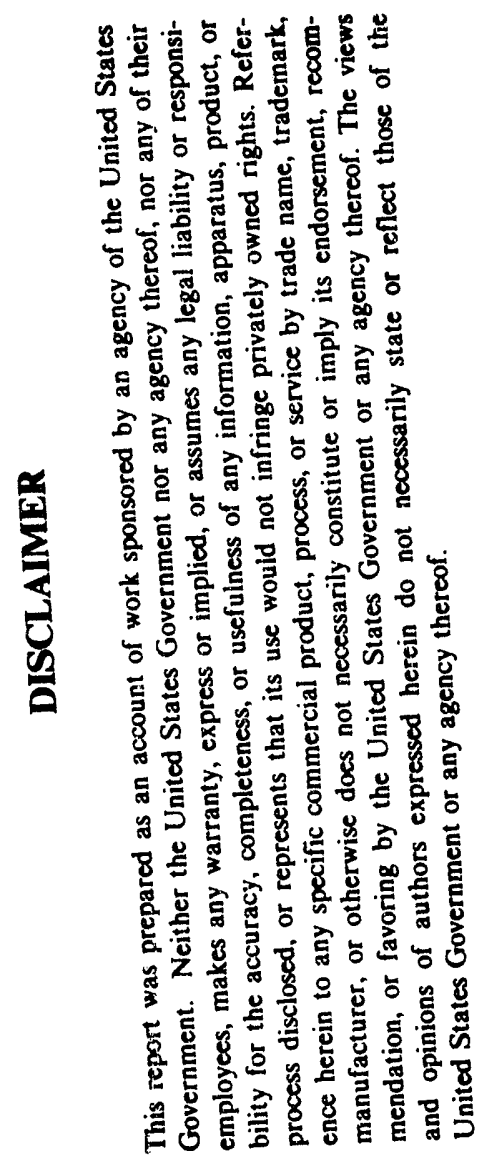

\author{
Anil S. Menawat \\ Department of Chemical Engineering \& \\ Molecular \& Ceilular Biology Program \\ Tulane University \\ New Orleans, LA 70118
}

Sept. 21, 1992

National Institute for Global Environmental Change

South East Division

Department of Energy 
Abstract:

The objective of this study was to investigate the role of oceanic carbon chemistry in modulating the atmospheric levels of $\mathrm{CO}_{2}$. It is well known that the oceans are the primary sink of the excess carbon pumped into the atmosphere since the beginning of the industrial period. The suspended particulate and the dissolved organic matters in the deep ocean play important roles as carriers of carbon and other elements critical to the fate of $\mathrm{CO}_{2}$. In addition, the suspended particulate matter provides sites for oxidation-reduction reactions and microbial activities. The problem is of an intricate system with complex chemical, physical and biological processes. This report describes a methodology to describe the interconversions of different forms of the organic and inorganic nutrients, that may be incorporated in the ocean circulation models. Our approach includes the driving force behind the transfers in addition to balancing the elements. Such thermodynamic considerations of describing the imbalance in the chemical potentials is a new and an unique feature of our approach.

\section{Introduction:}

The mean global temperature rose by about $1.6^{\circ} \mathrm{C}$ in last three decades. Half of this rise is attributable to the increase in the atmospheric carbon dioxide. All other greenhouse gases, like CFC's, methane etc., all together are responsible for the other half [1]. When all the sinks and sources for the world carbon are compared, the world oceans clearly are the largest. They are the ultimate sink for the atmospheric carbon dioxide. The largest fluxes in the global carbon cycle are those that link atmospheric carbon dioxide to land vegetation and to the oceans. The flux of $\mathrm{CO}_{2}$ to the oceans and to the land vegetation are of similar magnitudes. Using the best models of ocean circulation and $\mathrm{CO}_{2}$ dissolution in sea water, we believe that about $40 \%$ of the $\mathrm{CO}_{2}$ released from fossil fuels enters the ocean each year. Tans et al. [2] recently estimated the oceanic uptake of $\mathrm{CO}_{2}$ as $1.6 \times 10^{15} \mathrm{gC} / \mathrm{yr}$.

Present models use the flux balancing approaches by age equation. Mineralization rates are estimated with constant $\mathrm{C} / \mathrm{N}$ ratio with a total disregard to the specific biological and chemical activities. In this report we describe a technique that can be effectively used with currently available data. The crux of the technique lies in recognizing the biological and the chemical activities through their driving forces. All processes are treated as oxidation-reduction reactions. By an oxidation-reduction process we mean a transfer of electrons from one moiety to another. Their affinities, hence the extent of reactions, can therefore be easily defined with the total electron exchange in the process. The fluxes are thus calculated with the degree of reduction, availability of the electrons for transfer. The advantage of such an approach is obvious that it relies on the nonequilibrium thermodynamics instead of simple mass balancing by some inter conversion ratios like Redfield ratios. Elemental balances serve as constraints. 


\section{Eiochemical processes in the ocean:}

Carbon dioxide in the atmosphere is affected by processes that operate at different time scales. These include interactions with silicate cycle, dissolution in the oceans, and annual cycles of photosynthesis and respiration. $\mathrm{CO}_{2}$ is not reactive with other atmospheric constituents, and its mean residence time of 3 years in atmosphere is largely determined by the exchange with sea water [3]. The current increase in atmospheric $\mathrm{CO}_{2}$ is caused by the combustion of the fossil fuels and the destruction of land vegetation. When these processes attenuate, aimospheric $\mathrm{CO}_{2}$ will come into equilibrium. Nearly all of the $\mathrm{CO}_{2}$ released will reside in the ocean. In the meantime, higher concentrations of $\mathrm{CO}_{2}$ will contribute to the atmospheric warming through the "greenhouse effect."

As much as half of the global net primary production occurs in the sea. Primary production in the ocean is the removal of dissolved inorganic $\mathrm{CO}_{2}$ and nutrients to phytoplankton by photosynthesis. Phytoplankton production occurs in the surface mixed layer where the distribution of dissolved oxygen is an indirect measure of the rate of photosynthesis. Zooplankton and free-living bacteria, called bacterioplankton, in the surfac: waters consume most of the marine primary production. Zooplankton are the first link in the tropic chain leading to the large consumers like fish. A large population of bacteriovores consume the bacteria mineralizing the nutrients and releasing $\mathrm{CO}_{2}$ in the surface waters. Cole et al. [4] found that bacterial growth is about twice that of zooplankton and consumes $40 \%$ of the net primary production in the photic zone. Cho and Azam [5] also concluded that free-living bacteria are more important than zooplankton in the consumption of particulate organic carbon in the ocean. Thus, a large fraction of the carbon fixer in net primary production in the sea does not pass through the higher tropic levels [6]. When bacterial growth is inhibited by cold waters, more net primary production is available to consumers [7].

There is a gereral consensus that about $90 \%$ of the net primary production is degraded to inorganic compounds $\left(\mathrm{CO}_{2}, \mathrm{NO}_{3}, \mathrm{PO}_{4}\right.$, etc. $)$ in the surface waters. The remainder sinks below the euphotic zone the deep ocean. The estimates of sinking are constrained because greater rates of sinking would remove unreasonably large quantities of nutrients from the surface waters $[8,9]$. Bacterial degradation continues as particulate organic material (POM) sinks through the water column of the deep ocean. The mean sinking rate is about $350 \mathrm{~m} /$ day, so an average particle spends about 10 days in transit to the bottom [10]. Bacterial respiration accounts for the consumption of $\mathrm{O}_{2}$ and the production of $\mathrm{CO}_{2}$ in the deep ocean. Honjo et al. [10] found that the respiration rates averaged $2.2 \mathrm{mg} \mathrm{C} \mathrm{m}^{-2}$ day $^{-1}$ in the deep ocean, where the rate of bacterial respiration is probably limited by cold temperatures. About $95 \%$ of the particulate carbon degrades within the top $3000 \mathrm{~m}$ with only small quantities reaching the sediments of the deep ocean [11]. Significant rates of decomposition continue in the sediments. The ultimate burial of organic carbon is much less than $1 \%$ of the marine net primary production.

A large number of marine organisms precipitate carbonate in skeletal and protective tissues. Clams, oysters, and other shellfish are obvious examples, but a large 
quantity of $\mathrm{CaCO}_{3}$ is contained in foraminifera, pteropods, and other small zooplankton found in the sea [12]. The cocolithophores, a group of marine algae, are responsible for a large amount of $\mathrm{CaCO}_{3}$ deposited on the sea floor of the open ocean. The annual production of $\mathrm{CaCO}_{3}$ by these organisms is much larger than the supply of $\mathrm{Ca}$ to the oceans in river flow [8]. However, not all of the $\mathrm{CaCO}_{3}$ produced is stored permanently in the sediment.

Carbon dioxide is produced in the deep ocean by degradation of the organic materials that sink from the surface waters. As a result of their long isolation from the atmosphere, deep ocean waters are supersaturated with $\mathrm{CO}_{2}$. Progressive accumulation continues as a result of respiration. $\mathrm{CO}_{2}$ is also more soluble in water at the colder temperature and the higher pressure in the deep ocean. The accumulation of $\mathrm{CO}_{2}$ makes the deep waters undersaturated with $\mathrm{CaCO}_{3}$, as a result of the formation of carbonic acid:

$$
\mathrm{H}_{2} \mathrm{O}+\mathrm{CO}_{2} \leftrightarrow \mathrm{H}^{+}+\mathrm{HCO}_{3}^{-} \leftrightarrow \mathrm{H}_{2} \mathrm{CO}_{3}
$$

When the skeletal remains of the $\mathrm{CaCO}_{3}$ - producing organisms sink to the deep ocean, they dissolve

$$
\mathrm{CaCO}_{3}+\mathrm{H}_{2} \mathrm{CO}_{3} \leftrightarrow \mathrm{Ca}^{2+}+2 \mathrm{HCO}_{3}^{-}
$$

The dissolution increases the alkalinity in the deep ocean.

\section{Current State of Models of the Carbon Cycle in the Ocean:}

The surface waters are in theoretical equilibrium with atmospheric $\mathrm{CO}_{2}$ due to the dissolution of $\mathrm{CO}_{2}$ in sea water to form bicarbonate $\left(\mathrm{HCO}_{3}{ }^{-}\right)$. However, as a consequence of photosynthesis, the surface ocean remains undersaturated with $\mathrm{CO}_{2}$. Sinking organic materials remove $\mathrm{HCO}_{3}$ - from the surface and it is replaced by the dissolution of new $\mathrm{CO}_{2}$ from the atmosphere. The production and sinking of $\mathrm{CaCO}_{3}$ also delivers calcium to the deep ocean. $\mathrm{CaCO}_{3}$ carries the equivalent of one $\mathrm{CO}_{2}$ and leaves behind another equivalent in the surface waters; that is

$$
\mathrm{Ca}^{2+}+2 \mathrm{HCO}_{3}^{-} \rightarrow \mathrm{CaCO}_{3} \downarrow+\mathrm{H}_{2} \mathrm{O}+\mathrm{CO}_{2}
$$

Globally the $\mathrm{CO}_{2}$ in the form of $\mathrm{CaCO}_{3}$ is about four times larger than the sink in organic sediments [13], but only the organic sediments will increase in response to the increased atmospheric $\mathrm{CO}_{2}$. In the rest of the ocean, $\mathrm{CaCO}_{3}$ will dissolve create a sink for the $\mathrm{CO}_{2}$ in the form of bicarbonate.

Equilibrium dissolution of $\mathrm{CO}_{2}$ is described by the Henry's law. The amount that dissolves depends on the concentration of the $\mathrm{CO}_{2}$ in the overlying atmosphere and the temperature of the sea water. For example, twice as $\mathrm{CO}_{2}$ dissolves in water at $0^{\circ} \mathrm{C}$ as at $20^{\circ} \mathrm{C}$. Hence, $\mathrm{CO}_{2}$ enters the deep ocean with the downward flux of cold water at polar regions. Most $\mathrm{CO}_{2}$ in the deep ocean returns to atmosphere when cold, deep waters 
upwell at tropical latitudes. Time scale for this, however, is in hundreds of thousands of years.

A large number of models have been developed to explain the response of the ocean to higher concentrations of atmospheric $\mathrm{CO}_{2}[14,15]$. Most of these models are constructed to follow parcels of water as they circulate in a simplified ocean basin and to calculate the diffusion of $\mathrm{CO}_{2}$ between layers that do not mix directly. Figure 1 shows such a multi-box model in which the surface ocean is divided into cold polar waters and

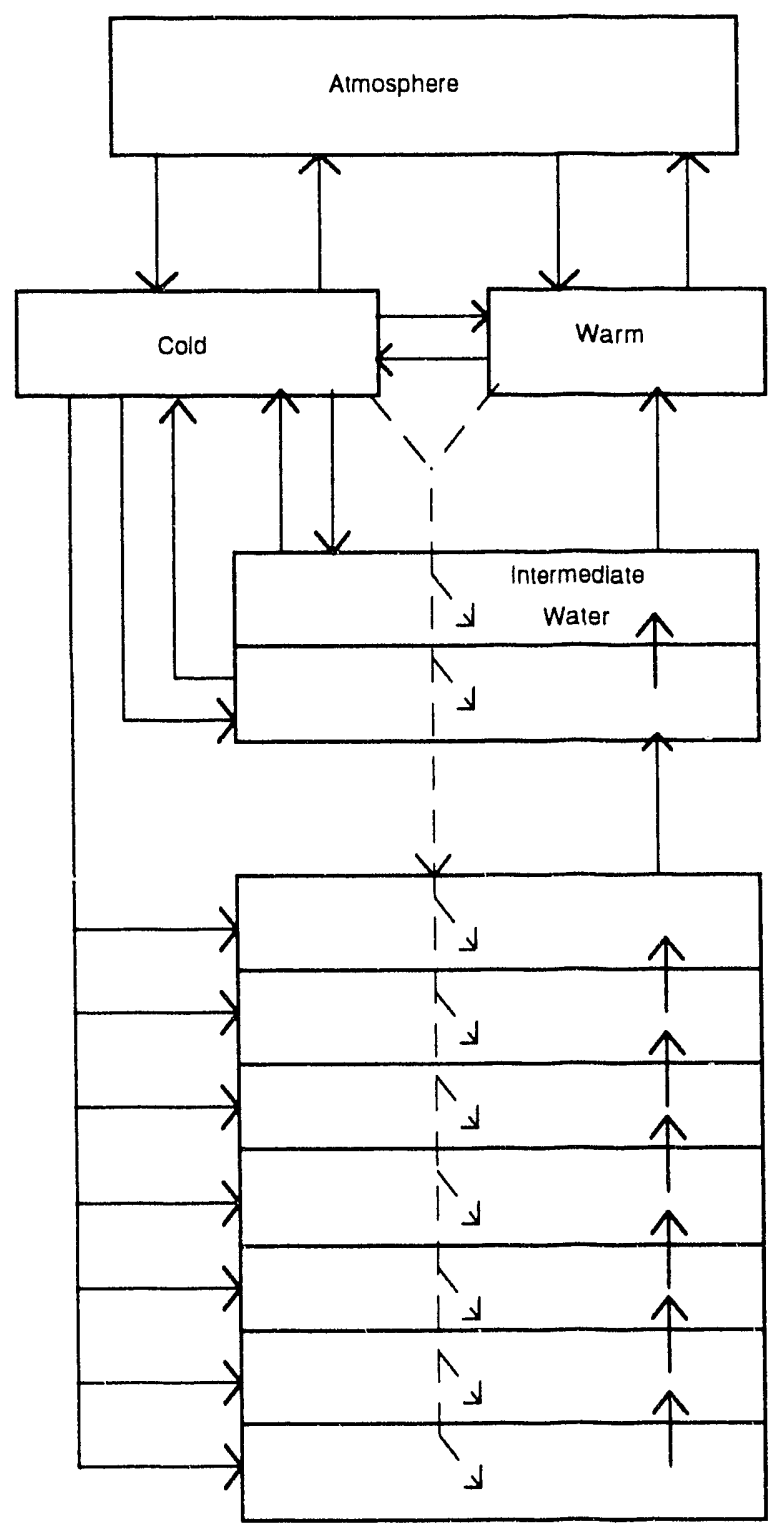

Figure 1: A box diffusion model for the oceans. Surface layer is divided into cold polar and warm tropical waters. Cold waters mix with deeper waters by downwelling. Other exchanges are by diffusion only. 
warmer waters at other latitudes. In such a model the colder water moves downward at the poles and mixes with the deep layers of ocean. The upwelling returns the deep water to surface. This is a diffusion and advection model where the rate of mixing is calculated from oceanographic data of the rate of ${ }^{14} \mathrm{C}$ and ${ }^{3} \mathrm{H}_{2} \mathrm{O}$ from atomic bombs has mixed into the ocean [16]. The models adjust the chemistry in each layer according to the carbonate equilibrium reactinns. These ocean models do not incorporate the effects of the biotic productivity in the sea. Although it has been long recognized to be of importance but the accuracy in estimating the new production are questionable [17, 18]. Sarmiento et al. [19] have recently suggested use of ${ }^{228} \mathrm{Ra}$ for estimating oxygen utilization rates.

\section{Nutrient Cycling in the Ocean:}

Net primary production in the sea is limited by the nutrients. The downward sinking of dead organisms and fecal pellets continuously remove the nutrients from the surface water. Each day, sinking removes $4-22 \%$ of particulate organic nitrogen from the surface waters. The concentrations of available $\mathrm{N}, \mathrm{P}$, and $\mathrm{Si}$ are low in the open oceans and high in the continental shelf and regions of upwelling. They are much higher in the deep ocean where the nutrients are regenerated.

In 1958, Albert Redfield [20] published a seminal paper where he noted that the chemical composition of the organic debris falling to the deep ocean contained $\mathrm{N}$ and $\mathrm{P}$ in a fairly constant atomic ratio to its carbon content: $80 \mathrm{C}: 15 \mathrm{~N}: 1 \mathrm{P}$. Whereas the ratio in upwelling waters is $800 \mathrm{C}: 15 \mathrm{~N}: 1 \mathrm{P}$ [21]. This restricts the amount of $\mathrm{HCO}_{3}$ consumption by photosynthesis to $10 \%$ only before the $\mathrm{N}$ and $\mathrm{P}$ would be exhausted. The remaining $\mathrm{HCO}_{3}$ would be lost to the atmosphere as $\mathrm{CO}_{2}$. The biotic growth therefore would be limited by the upwelling rates that regenerate the nutrient pool. The increase in the atmospheric $\mathrm{CO}_{2}$, hence the $\mathrm{HCO}_{3}$ in the surface water through equilibrium, would not regulate the biological activity. Broecker [8] recalculated Redfield ratios to include $\mathrm{CaCO}_{3}$. His modified ratio in sinking particles in $120 \mathrm{C}: 15 \mathrm{~N}: 1 \mathrm{P}: 40 \mathrm{Ca}$, whereas in the upwelling waters it is $800 \mathrm{C}: 15 \mathrm{~N}: 1 \mathrm{P}: 3200 \mathrm{Ca}$.

Redfield ratios suggests that the demand for $\mathrm{N}$ and $\mathrm{P}$ by phytoplankton is closely matched to their concentrations in upwelling waters. Both elements show low concentrations in surface waters and the concentrations of $\mathrm{N}$ and $\mathrm{P}$ are correlated with a slope near the Redfield ratio. There is, therefore, the possibility that both $\mathrm{N}$ anc $\mathrm{P}$ might simultaneously limit the marine productivity, in contrast to the widespread limicition by $\mathrm{P}$ in the freshwater. Howarth [22] proposed that net primary production in many ocean waters may show tendency of $\mathrm{N}$ limitation. The ultimate source of $\mathrm{P}$ for new production in the sea is through rivers. The N/P ratio in river flow is 4.4 , versus the Redfield ratio of 15 , nitrogen would naturally be limiting in the nearshore areas [23]. In the absence of additional sources of nitrogen, such as atmospheric deposition or nitrogen fixation, nitrogen would be the limiting nutrient in the oceans in general.

Nitrogen fixation in ocean is very limited [24]. Enzymes for nitrogen fixation require molybdenum and iron whereas Pearl et al. found that addition of these with phosphorous did not stimulate the nitrogen fixation, but the supply of dissolved organic 
carbon (DOC) was critical [25]. It, however, is entirely possible that DOC may not be as important as the chelators for Mo and Fe that would increase the availability to these elements to the $\mathrm{N}$ fixers [26,27]. Flocculation of organic matter in the sea, known as marine snow, creates small microzones of anaerobic conditions in which the availability of micronutrients and low redox potential could stimulate nitrogen fixation. These anaerobic microzones also allow significant rates of denitrification in the sea, despite the high redox potential of the sea water. The ocean is also a net source of $\mathrm{N}_{2} \mathrm{O}$ to the atmosphere which is a result of the denitrification in the water column.

Limited input of nitrogen in river waters and by nitrogen fixation, and the potential for large losses by denitrification, all reinforce $\mathrm{N}$ limitation in the sea. In most area of ocean, nitrate is not measurable in the surface waters, and phytoplankton respond to nanomolar additions of nitrogen to sea water [28].

Most net primary production is supported by nutrient mineralization in the surface waters and only small quantities of nutrients are lost to the deep ocean. For both elements, $\mathrm{N}$ and $\mathrm{P}$, the mean residence time of the available pool in the surface ocean is much than a year, while the mean residence time for the total pool is about ten years. Thus, each atom of $\mathrm{N}$ and $\mathrm{P}$ cycles through the biota many times. Upon sinking and mineralization in the deep ocean, $\mathrm{N}$ and $\mathrm{P}$ enter pools with a mean residence time of about 500 years. Their movement is largely controlled by the circulation of water through the deep ocean. Mineralization of $\mathrm{N}$ and $\mathrm{P}$ occurs more rapidly than $\mathrm{C}$ as particles settle through the deep waters, $\mathrm{C} / \mathrm{N}$ and $\mathrm{C} / \mathrm{P}$ ratio of particulate organic carbon increase with depth [10]. Current estimates of these fluxes carry large uncertainty. Nitrogen losses to the atmosphere roughly balance inputs from all sources, and there is little loss of $\mathrm{N}$ to sediment. Denitrification maintains a steady state in the marine biogeochemical cycle of $\mathrm{N}$. In the absence of denitrification, the ocean would have much higher concentration of nitrate and the atmosphere would have a much lower concentration of $\mathrm{N}_{2}$.

\section{The Model:}

The model comprises of equations of conservation at various levels in the ocean. We write the generalized equation for an infinitesimal volume, V, and any extensive property $E$ of the system. It is

$$
E=\int_{V} e d v
$$

The intensive quantity $e$ is the volume density of the property $E$. The extensive property $E$ may be exchanged with the surroundings by crossing the system boundary, and it can be generated or consumed in the system's internal processes. Equation (1) can, therefore, be rewritten as

$$
\dot{E}=\Pi_{E}+\Phi_{E}
$$


Here $\Pi_{E}$ represents the rate of production (or consumption) of $E$ in the system and $\Phi_{E}$ represents the rate of exchange of $E$ with the surroundings. By analogy to Equation (1), the rate of production of $E$ is as follows

$$
\Pi_{E}=\int_{V} r_{E} d v
$$

where $r_{E}$ is the rate of production of $E$ per unit volume. Similarly, the surface density of transport is

$$
\Phi_{E}=\int_{S} n j_{E} d S
$$

in which $\boldsymbol{n}$ is the inward normal on the surface of the system and $\boldsymbol{j}_{\boldsymbol{E}}$ is the surface density of rate of transport to the system. Combining the Equations (1) through (4) for a homogeneous system with constant volume, a simpler equation emerges

$$
\dot{e}=r_{E}+\varphi_{E}
$$

where $\varphi_{E}=\Phi_{E} / V$. Furthermore, the net production rate for a conserved quantity is identically equal to zero for it can not be created or destroyed. That is, $r_{E}=0$. Equation (5) for such a system reduces to

$$
\dot{e}=\varphi_{E}
$$

If there are $k$ chemical elements present in $n$ compounds, the elemental composition matrix $\boldsymbol{E}$, an $n \times k$ matrix, is defined whose members, $e_{i j}$, represent the amount of chemical element $i$ in compound $j$. Since chemical elements are conserved, Equation (6) at steady state becomes

$$
\varphi \boldsymbol{E}=0
$$

This is the principle of elemental conservation that serves as a constraint for our model.

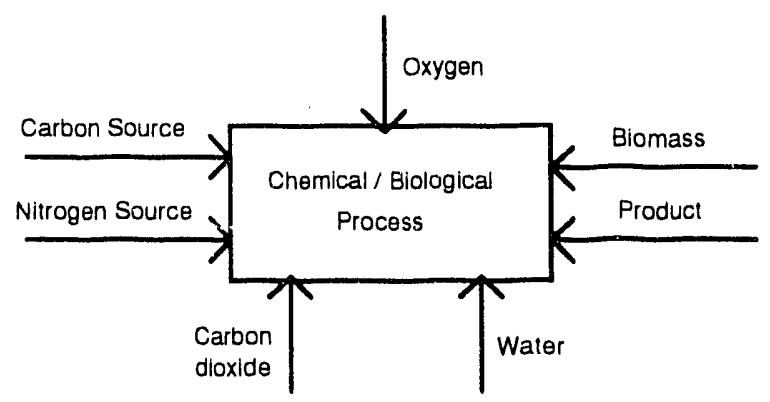

Figure 2: System description of a chemical or biological process with respective flows. This model exemplifies the aerobic biomass production. 
Let us consider a chemical or biological phenomenon as described in Figure 2. We shall select the basis as one carbon atom. The flow vector, $\varphi$, is of dimensionality seven and the elemental composition matrix, $\boldsymbol{E}$, is as follows:

$$
\boldsymbol{E}=\left[\begin{array}{cccc}
1 & a_{1} & b_{1} & c_{1} \\
1 & a_{2} & b_{2} & c_{2} \\
1 & a_{3} & b_{3} & c_{3} \\
d_{4} & a_{4} & b_{4} & c_{4} \\
0 & 0 & 2 & 0 \\
1 & 0 & 2 & 0 \\
0 & 2 & 1 & 0
\end{array}\right] \quad \cdots \quad\left\{\begin{array}{c}
\text { Biomass } \\
\text { Carbon Source } \\
\text { Product } \\
\text { Nitrogen Source } \\
\text { Oxygen } \\
\text { Carbon dioxide } \\
\text { Water }
\end{array}\right\}
$$

Each column represents the elements - C, H, O, N.

For the above system, Equation (7) describes four linear equations among the seven flows. Three of the seven flows, therefore, must be known to calculate the others. If we were to assume the flows for biomass, $\varphi_{1}$, for carbon source, $\varphi_{2}$, and for product, $\varphi_{3}$, we could calculate the rest of the flows. The known flows are related with macroscopic yields of the compounds per C-mole basis. Whereas the remaining four flows can be related with the concept of "degree of reduction" introduced by Minkevich \& Eroshin [29] and later refined by Erickson [30]. The degree of deduction is the number of electrons available for transfer to oxygen on combustion of a compound. The degree of reduction of a compound of elemental composition $\mathrm{CH}_{\mathrm{ai}} \mathrm{O}_{\mathrm{bi}} \mathrm{N}_{\mathrm{ci}}$ becomes:

$$
\gamma_{i}^{\prime}=4+a_{i}-2 b_{i}+5 c_{i}
$$

The multiplication factors are equivalent to the respective valences of the elements. The valence of nitrogen is +5 because of nitrates. It is the dominant form in which nitrogen is present in the ocean [31].

The above approach of defining the degree of reduction to each molecule that is consumable or produced provides a convenient method to properly describe the biological activities in the ocean. It is well known that all forms of organic molecules are not consumed by the organisms at the same rate and simultaneously. Certain substrates are preferred under given conditions. That may change with changing of the environment. It is, therefore, essential to describe the biological activity, particularly, over the whole water column with local conditions instead of treating the entire ocean as a homogeneous body, which it certainly is not. In making such a precise description, we risk loosing the workability of the model. However, recognizing the fact that all materials can be described by their degree of reduction, and the oxidation-reduction potential is the driving force for these processes, it is convenient to tag the organic molecules with their respective degree of reduction. Now the entire analysis can be performed at this thermodynamic platform instead of dealing with each chemical specie individually. Table 1 summarizes the results 
obtained for the PARFLUX P site in Central North Pacific ocean [32]. This is aerobic mineralization of the suspended particulate matter. It shows preferential uptake of substrates and production of nitrate.

TABLE 1 : Flow calculations at PARFLUX P site in Central North Pacific Ocean

\begin{tabular}{|l|c|ccccc|c|}
\hline \multicolumn{1}{|c|}{ Chemical } & & \multicolumn{5}{|c|}{ Flows at various Depth $\left(\mathbf{m m o l} / \mathbf{m}^{\mathbf{3}}\right)$} & $\begin{array}{c}\text { Give } \\
\mathbf{n}\end{array}$ \\
\hline Specie & $\boldsymbol{\gamma}$ & $\mathbf{3 7 8} \mathbf{~ m}$ & $\mathbf{9 7 8} \mathbf{~ m}$ & $\mathbf{2 7 7 8} \mathbf{~ m}$ & $\mathbf{4 2 8 0} \mathbf{~ m}$ & $\mathbf{5 5 8 2} \mathbf{~ m}$ & / Calc \\
\hline Amino Acid & 5.2 & $4.0 \times 10^{-4}$ & $7.0 \times 10^{-5}$ & $1.0 \times 10^{-4}$ & $8.0 \times 10^{-5}$ & $7.0 \times 10^{-5}$ & Given \\
Carbohydrate & 5.0 & $1.0 \times 10^{-4}$ & $9.0 \times 10^{-7}$ & $2.0 \times 10^{-4}$ & $2.0 \times 10^{-6}$ & $1.0 \times 10^{-6}$ & Given \\
CO 2 & $0.0 \times 10^{-4}$ & $9.0 \times 10^{-5}$ & $2.0 \times 10^{-6}$ & $1.0 \times 10^{-4}$ & $1.0 \times 10^{-4}$ & Given \\
Nitrate & 4.0 & -34.48 & -30.34 & -206.9 & -224.1 & -234.5 & Calc \\
Biomass & 5.8 & -34.48 & -30.34 & -206.9 & -224.1 & -234.5 & Calc \\
Oxygen & 0 & 50.0 & 44.0 & 300.0 & 325.0 & 340.0 & Given \\
\hline
\end{tabular}

Note: Negative value means production.

\section{Conclusions:}

Table 1 demonstrates the application of our modeling technique. All of the processes can be described in this matter and put together to compile the total picture. The approach does not require any radio tracer data. Data commonly collected for the organic and inorganic matter in ocean is sufficient. There is not need to make any assumptions about the diffusion coefficients in the age equations. Thermodynamic analysis ensures that processes described are realistic and occur in the ocean. 


\section{References:}

[1] Chemical and Engineering News. April 1986.

[2] Tans, P. P., I. Y. Fung and T. Takahashi. 1990. Observational constraints on the global atmospheric $\mathrm{CO}_{2}$ budget. Science. 247:1431-1438.

[3] Olson, J. S., R. M. Garrels, R. A. Berner, T. V. Armentano, M. I. Dyer and D. H. Yaalon. 1985. The natural carbon cycle. pp. 175-213. In J. R. Trabalka (ed.), Atmospheric Carbon Dioxide and the Global Carbon Cycle. U. S. Department of Energy, Washington, DC.

[4] Cole, J. J., S. Findlay and M. L. Pace. 1988. Bacterial production in fresh and saltwater ecosystems: a cross-system overview. Marine Ecology Prog. 43:1-10.

[5] Cho, B. C. and F. Azam. 1988. Major role of bacteria in biogeochemical fluxes i the ocean's interior. Nature. 332:441-443.

[6] Ducklow, H. W., D. A. Purdie, P. J. LeB. Williams and J. M. Davies. 1986. Bacterioplankton: A sink for carbon in a coastal marine plankton community. Science. 232: 865-867.

[7] Pomeroy, L. R. and D. Deibel. 1986. Temperature regulation of bacterial activity during the spring bloom in Newfoundland coastal waters. Science. 233: 359-361.

[8] Broecker, W. S. 1974. Chemical Oceanography. Harcourt Brace Jovanovich, New York.

[9] Eppley, R. W. and B. J. Peterson. 1979. Particulate organic matter flux and planktonic new production in the deep ocean. Nature. 282: 677-680.

[10] Honjo, S. S., J. Manganini and J. J. Cole. 1982. Sedimentation of biogenic matter in the deep ocean. Deep Sea Res. 29: 609-625.

[11] Martin, J. H., G. A. Knauer, D. M. Karl and W. W. Broenkow. 1987. VERTEX: Carbon cycling in the northeast Pacific. Deep Sea Res. 34: 267-285.

[12] Simkiss, K. and K. M. Wilbur. 1989. Biomineralization: Cell Biology and Mineral Deposition. Academic Press, San Diego.

[13] Li, Y. -H. 1972. Geochemical mass balance among lithoshere, hydrosphere, and atmosphere. Am. J. Sci. 272: 119-137.

[14] Bacastow, R. and A. Bjorkstrom. 1981. Comparisons of ocean models for the carbon cycle. pp. 29-79. In B. Bolin (ed.), Carbon Cycle Modeling. Wiley, New York. 
[15] Emanuel, W. R., I. Y. -S. Fung. G. G. Killough, B. Moore and T. -H. Ping. 1985. Modeling the global carbon cycle and changes in the atmospheric carbon dioxide levels. pp. 141-173. In J. R. Trabalka (ed.), Atmospheric Carbon Dioxide and the Global Carbon Cycle. U. S. Department of Energy, Washington, DC.

[16] Killough, G. G. and W. R. Emanuel. 1981. A comparison of several models of carbon turnover in the ocean with respect to their distributions of transit time and age, and responses to atmospheric $\mathrm{CO}_{2}$ and ${ }^{14} \mathrm{C}$. Tellus. 33: 274-290.

[17] Platt, T., W. G. Harrison, M. R. Lewis, W. K. W. Li, S Sathyendranath, R. E. Smith and A. F. Vezina. 1989. Biological production of the oceans: The case for a consensus. Mar. Ecol. Prog. Ser. 52: 77-88.

[18] Eppley, R. W. 1989. New production: History, methods, problems. pp. 85-97. In W. H. Berger, U. S. Smetacek and G. Wefer (eds.), Productivity of the Ocean: Present and Past. John Wiley. New York.

[19] Sarmiento, J. L., G. Thiele, R. M. Key and W. S. Moore. 1990. Oxygen and nitrate new production and remineralization in the North Atlantic Subtropical Gyre.

[20] Redfield, A. C. 1958. The biological conto! of chemical factors in the environment. Amer. Scientist. 46: 205-221.

[21] Redfield, A. C., B. H. Ketchum and F. A. Richards. 1963. The influence of organisms on the composition of sea-water. pp. 26-77. In M. N. Hill (ed.), The Sea, Vol. 2. Wiley, New York.

[2.2] Howarth, R. W. 1988. Nutrient limitation of nêे primary production in marine ecosystems. Ann. Rev. Ecol. System. 19: 89-110.

[23] Ryther, J. H. and W. M. Dunstan. 1971. Nitrogen, phosphoi us, and eutrophication in the coastal marine environment. Science. 171: 1008-1013.

[24] Howarth, R. W., R. Marino, J. Lane and J. J. Cole. 1988. Nitrogen fixation in freshwater, estuarine, and marine ecosystems. 1. Rates and importance. LImnol. Oceanography. 33: 669-687.

[25] Paerl, H. W., K. M. Crocker and L. E. Prufert. 1987. Limitation of $\mathrm{N}_{2}$ fixation in coastal marine waters: Relative importance of molybdenum, iron, phosphorus, and organic matter availability. Limnol. Oceanography. 32: 525-536.

[26] Howarth, R. W., R. Marino and J. J. Cole. 1988. Nitrogen fixation in freshwater, estuarine, and marine ecosystems. 2. Biogeochemical controls. Limnol. Oceanography. 33: 688-701. 
[27] Paerl, H. W. and R. G. Carlton. 1988. Contre' of nitrogen fixation by oxygen depletion in surface-associated microzones. Nature. 332: 260-262.

[28] Glover, H. E., B. B. Prezelin, L. Campbell, M, Wyman and C. Garside. 1988. A nitrate-dependent Synechococcus bloom in surface Sargasso sea water. Nature. 331: $161-163$.

[29] Minkevich, I. G. and V. K. Eroshin. 1973. Folia Microbiol. 18: 376.

[30] Erickson, L. E., I. G. Minkevich and V. K. Eroshin. 1978. Application of mass and energy balance regularities in fermentation. Biot?ch. Bioeng. 20: 1595-1621.

[31] Lee, C. and S. G. Waksham. 1988. Organic matter in seawater: Biogeochemical Processes. Chem. Oceanography. 9: 1-51.

[32] Wakeham, S. G., C. Lee, J. W. Farrington and R. B Gagosian. 1984. Biogeochemistry of particulate organic matter in the oceans: Results from sediment trap experiments. Deep Sea Res. 31: 509-528. 


